\title{
Settlement Analysis of a Confined Sand Aquifer Overlain by a Clay Layer due to Single Well Pumping
}

\author{
Wen-jie Niu, ${ }^{1}$ Zhenyu Wang, ${ }^{2}$ Feng Chen, ${ }^{2}$ and Hongran $\mathrm{Li}^{3}$ \\ ${ }^{1}$ College of Mechanics and Engineering Department, Liaoning Technical University, Fuxin, Liaoning 123000, China \\ ${ }^{2}$ College of Civil Engineering and Architecture, Zhejiang University, Hangzhou, Zhejiang 310058, China \\ ${ }^{3}$ Shanghai Geotechnical Investigations \& Design Institute Co., Ltd., Shanghai 200031, China \\ Correspondence should be addressed to Zhenyu Wang; wzyu@zju.edu.cn
}

Received 21 November 2012; Revised 16 January 2013; Accepted 17 January 2013

Academic Editor: Fei Kang

Copyright (C) 2013 Wen-jie Niu et al. This is an open access article distributed under the Creative Commons Attribution License, which permits unrestricted use, distribution, and reproduction in any medium, provided the original work is properly cited.

\begin{abstract}
This paper proposes a simplified analytical solution to determine the primary consolidation settlement of a confined sand aquifer overlain by a clay layer due to single well dewatering. After single well pumping in a steady state, the Dupuit equation predicts the confined sand aquifer water head drawdown. The confining pressure on the underlain confined sand aquifer top surface is determined using the principle of vertical force equilibrium. Additional vertical stresses in each layer of the confined sand aquifer are then computed with the Boussinesq solution. The overall aquifer consolidation deformation is then determined with the $e$-lg $p$ curve from the one-dimensional consolidation test and the applied vertical stress with the integral method. The proposed analytical solution is validated using the ADINA software, where porous media are simulated with the Biot model and solved with the 3D finite element method. This proposed analytical solution is used to simulate the primary consolidation settlement due to well pumping, using the fourth confined aquifer in the Pudong New Area of Shanghai from 1980 to 1995 as a case study. The predicted settlement compares reasonably well with the actual measured settlement in Shanghai.
\end{abstract}

\section{Introduction}

With ever-increasing groundwater demands for domestic and industrial uses, loss of land due to well pumping has become a disastrous phenomenon in many cities worldwide $[1,2]$. The consequences of well pumping include damage to underground utility lines, seawater intrusion, destabilisation of existing infrastructure, and ground fractures. Therefore, land subsidence by well pumping is a worldwide problematic issue that must be promptly addressed [3-7].

As a generalisation, land subsidence induced by well pumping is explained by groundwater flow and subsidence models [5, 8]. Previous subsidence research was concerned mainly with the compression of clay layers. Most models have represented compaction by incorporating Terzaghi's one-dimensional compaction principle into the groundwater flow equation [9-12]. However, because Terzaghi's onedimensional compaction principle is valid only for a onedimensional compaction case and was originally concerned with the dissipation of pore water pressure, the Biot theory remains the only suitable fully coupled land subsidence model [13, 14]. Various aspects of compaction, such as stress-dependent storage properties, dependence of hydraulic conductivity on compaction [15], and the effects of moving water tables [16], may also be included in Terzaghi's model or the Biot model.

However, the extraction of a sand aquifer water could also give rise to land subsidence. For example, since the 1980s, the fourth confined aquifer of Shanghai city has been the main confined aquifer for groundwater extraction and has contributed greatly to the total subsidence of Shanghai. In predicting the settlement of a sand aquifer, the fully coupled Biot model, while appropriate, is inconvenient to use and may not be the best choice because of its many parameters and reliance on advanced software for computation. Moreover, applying Terzaghi's 1D compaction principle to a sand aquifer is meaningless because the sand aquifer consolidates instantaneously and Terzaghi's 1D compaction principle is suitable only for low permeability soils (e.g., clay). 
For a confined sand aquifer overlain and confined by an impermeable clay layer, seepage of groundwater forms a depression cone when groundwater is pumped from a well [17]. The vertical hydraulic pressure in the confined sand aquifer against the bottom of the upper confining layer decreases during pumping. Increases in intergranular pressure among sand particles in confined sand aquifers are generated due to the pressure from the overlain confining impermeable clay layer [18]. Compression of sand particles gives rise to confined aquifer compressive deformation and contributes to the total subsidence of all layers.

Corresponding research on settlement analysis of confined aquifers can be found in the following references. Sun et al. used the storativity, specific storage, and hydrological information to estimate the elastic and inelastic compaction of the soil layers due to fluid withdrawal with a series of equations [19]. Chen et al. proposed a three-dimensional numerical model that couples the groundwater flow and soil consolidation to investigate the mechanisms of ground settlement [20]. Roy and Robinson performed a series of in situ soil experiments to calibrate the prediction model and used computer program SEEP/W version 4.23 in the seepage analyses [21]. Li et al. used the statistical procedure and fractal concept to analyse land subsidence caused by groundwater exploitation in the Hangzhou-Jiaxing-Huzhou plain in China [22]. Shi et al. obtained groundwater level and subsidence monitoring data from 27 extensometer groups and more than 1,000 observation wells in the Shanghai area. The relationship between the deformation and the groundwater level was analysed [23]. Wu et al. developed a nonlinear coupled regional land subsidence model. The coupled model consists of a three-dimensional groundwater flow model and a onedimensional vertical deformation model based on viscoelastoplastic constitutive laws, called the modified merchant model, and then is solved using a multiscale iterative finite element method. The calibrated and evaluated model is then used to assess the future evolution of land subsidence under two groundwater pumping scenarios [24]. Solutions to the above models of confined aquifers are either numerical solutions or statistical analyses of field monitoring data. A simple, cost-effective method for engineers to predict confined sand aquifer settlement by well pumping would indeed prove valuable, although such simplified formulations are not well illustrated in the literature [25].

This paper proposes an approximate analytical solution for land subsidence induced by the confined sand aquifer consolidation due to single well pumping. In the model, a confined sand aquifer is overlain by a low permeability clay layer, and the confined aquifer is pumped by a single well. The water head drawdown in the confined sand aquifer is predicted with the Dupuit equation. The confined sand aquifer consolidates transiently due to the pressure from the impermeable confining layer, and the primary consolidation settlement manifests immediately. The resultant effective stress increase in the confined sand aquifer due to the pressure from the upper impermeable confining layer is determined using the Boussinesq solution [26]. The primary consolidation settlement of the confined sand aquifer is determined using the $e-\lg p$ curve method [27]. The proposed analytical solution is compared to the numerical result found via the ADINA software where the porous medium is simulated with the Biot model and solved with the $3 \mathrm{D}$ finite element method. The Shanghai fourth confined sand aquifer settlement induced by well pumping from 1980 to 1995 is reasonably well predicted with the proposed analytical solution.

\section{Theory of the Analytical Solution for Predicting a Confined Aquifer Consolidation Settlement at a Single Well in a Steady Seepage State}

The method is based on an assumption of steady state, axisymmetric drawdown around a single well. Water head drawdown is predicted with the Dupuit equation, and then the confining pressure on the confined aquifer is determined. Additional vertical stress in the confined aquifer is computed using a 2D Boussinesq expression in terms of radial and depth variables. The void ratio change under the vertical stress is determined with the $e-\lg p$ curve from a one-dimensional consolidation test. The vertical element's consolidation deformation is then determined from the void ratio change. The overall consolidation settlement of the confined aquifer is then determined with the integral method. Details are presented below.

2.1. 2D Seepage Analysis and Water Head Prediction of the Confined Aquifer. In theory, an area is dewatered by a single well. The single well penetrates through the upper confining clay layers into a confined sand aquifer with an impervious bottom layer. The water head drawdown of the confined sand aquifer is presented in Figure 1. Under these conditions, ground subsidence occurs. Before studying the subsidence, the water head in the confined sand aquifer in Figure 1 must first be determined. The model for studying the water head variation in the confined sand aquifer induced by single well dewatering is presented in Figure 2. For the confined aquifer in Figure 2, the radial flow to the pumped well is steady state [28]. The pumped district boundary is surrounded with potential sources of recharge water (e.g., a large lake, a river, or the sea) that remain at a constant level. A balance exists between the pumping water and the recharge water for the confined aquifer in Figure 2.

A systematic analysis of the water head is expressed in Figure 2. With the Dupuit-Forchheimer approximation, where the vertical resistance to flow is neglected, water head drawdown $s$ at a point with horizontal distance $r$ to the well is given as follows [29-31]:

$$
s=H_{0}-h=\frac{Q}{2 \pi K M} \ln \frac{R}{r},
$$

where $Q$ denotes the well discharge, $K$ denotes the confined aquifer hydraulic conductivity, $M$ denotes the saturated confined aquifer thickness, and $R$ denotes the confined aquifer radius. If the model in Figure 2 cannot be found in the field, the Sichardt equation to determine the influence radius $R=$ $3000 s_{w} \sqrt{K}$ can be used instead [28], where $s_{w}$ denotes the water head drawdown at the well. 


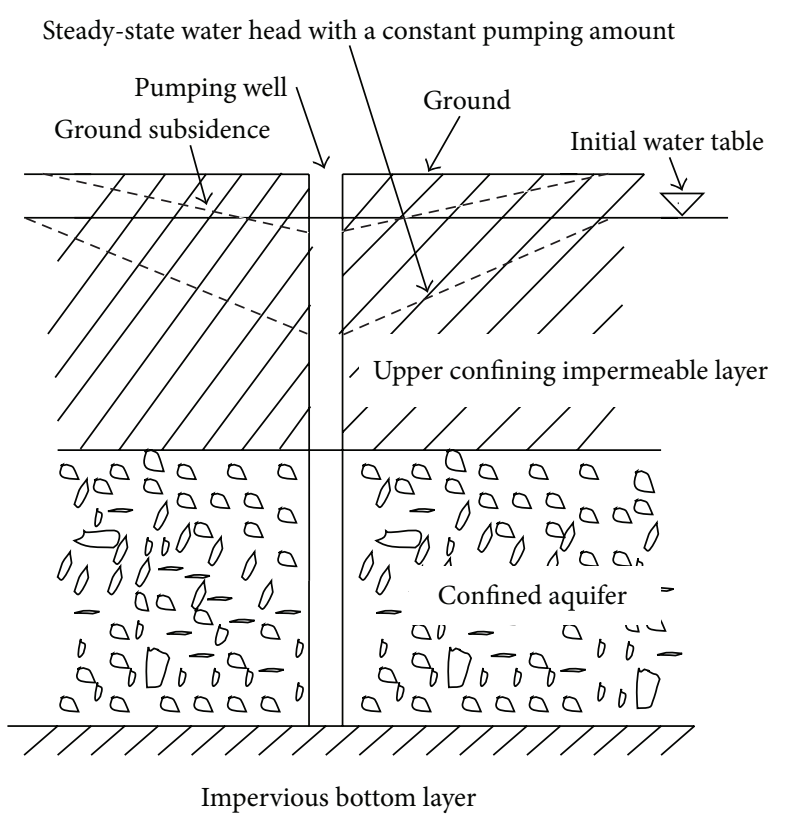

Figure 1: Dewatering in a confined sand aquifer overlain by a low permeability clay layer.

In Figure 2, the water head at distance $r$ can also be derived as follows $[29,30]$ :

$$
h-h_{w}=\frac{Q}{2 \pi K M} \ln \frac{r}{r_{w}},
$$

where $h_{w}$ denotes the water head at the well face and $r_{w}$ denotes the well radius. Equation (2) can be transformed as follows:

$$
s=H_{0}-h_{w}-\frac{Q}{2 \pi K M} \ln \frac{r}{r_{w}}=s_{w}-\frac{Q}{2 \pi K M} \ln \frac{r}{r_{w}} .
$$

In the remainder of this paper, the water head drawdown $s$ in the confined aquifer is predicted with (1) because the hydraulic boundary is circular or could be assumed as circular with the assistance of the influence radius [32]. If the confined aquifer recharge water boundary geometry is complex, a 2D finite element program can be employed to study the water head drawdown due to well pumping [33].

2.2. Initial Effective Stress in the Confined Aquifer before Pumping. The initial confining pressure on the confined aquifer induced by the self-weight of the upper confining impermeable clay layer in Figure 2 is given as follows:

$$
p_{1}=D \gamma_{1}
$$

where $D$ denotes the thickness of the confining layer and $\gamma_{1}$ denotes the confining layer impermeable clay unit weight. Figure 3 is a detailed presentation of Figure 2.

According to Karl von Terzaghi's Principle, if it is assumed that normal consolidation occurs in the confined aquifer before pumping in Figure 3 where $Q$ is zero, the initial

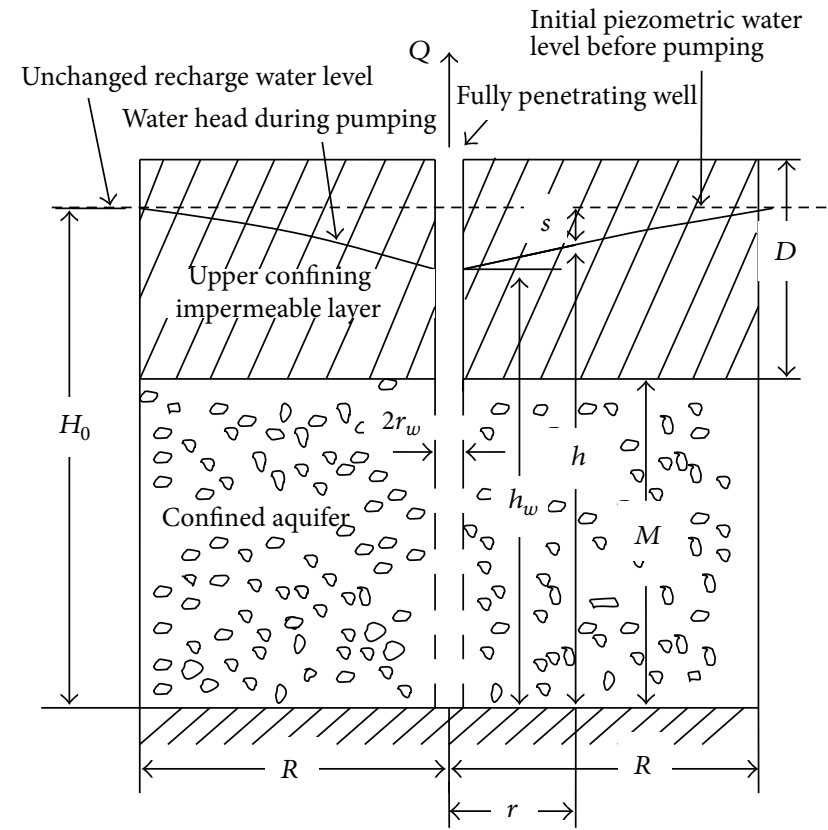

FIGURE 2: An idealised model for the determination of water head drawdown in a confined aquifer pumped by a well.

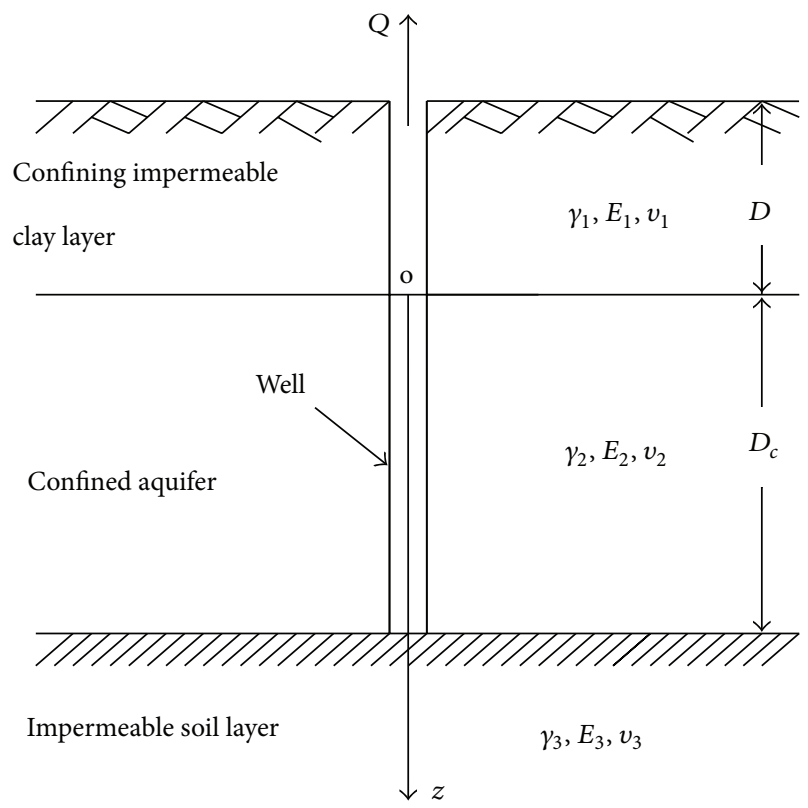

FIGURE 3: A simplified analysis scheme for the confined aquifer pumped by a well.

effective stress in the confined aquifer at a point of depth $z$ is given by

$$
p_{0}=D \gamma_{1}+z \gamma_{2}-\left(H_{0}-D_{c}+z\right) \rho_{w} g
$$

where $D_{c}$ denotes the confined aquifer thickness, $\gamma_{2}$ denotes the confined aquifer sand unit weight in Figure 3 , and $z$ denotes the depth of the studied point in the confined aquifer, as shown in the $z-r$ cylindrical coordinate system in Figure 4. 
Increased pressure from overlain clay layer applied on the confined aquifer top surface due to a single well dewatering

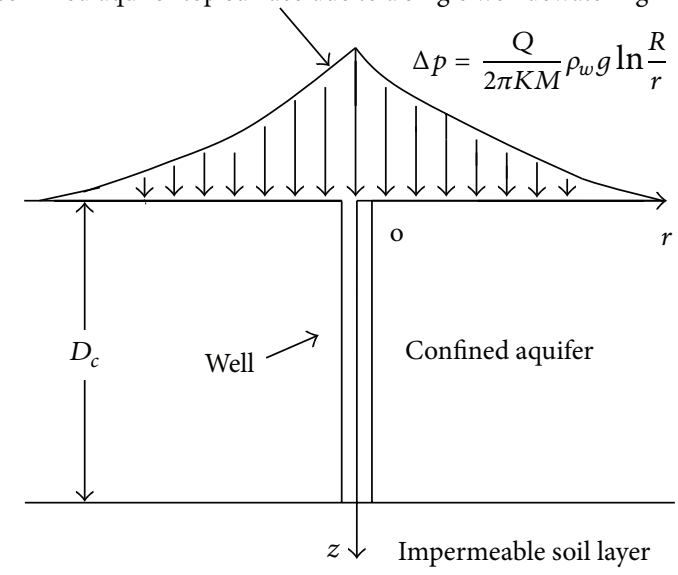

FIGURE 4: Increased pressures applied on the confined aquifer in a $2 \mathrm{D}$ view.

The origin o of the $z-r$ cylindrical coordinate system in a single well is on the contact surface between the upper confining layer and the confined aquifer. Figure 4 is a detailed presentation of Figure 3.

\subsection{Effective Stress Increase in the Confined Aquifer}

2.3.1. Confining Pressure from the Overlying Layer on the Confined Aquifer Upper Surface Induced by Pumping. Because of water head drawdown, the upward hydraulic pressure against the bottom of the upper confining layer decreases, and the intergranular pressure increases [18]. According to the principle of vertical force equilibrium, the increased pressure applied on the confined aquifer top surface due to pumping in Figure 3 can be derived as follows:

$$
\Delta p=s \rho_{w} g
$$

where $\rho_{w}$ denotes the water density, $s$ denotes the water head drawdown, and $g$ denotes gravitational acceleration.

As mentioned in (1), the water head drawdown $s$ can be predicted. By combining (1) and (6), the increased pressure applied on the confined aquifer top surface due to single well pumping can be derived as follows:

$$
\Delta p=\frac{Q}{2 \pi K M} \rho_{w} g \ln \frac{R}{r} .
$$

Figures 4 and 5 demonstrate the applied pressure on the confined aquifer in $2 \mathrm{D}$ and $3 \mathrm{D}$ views, where $A$ is defined as $(Q / 2 \pi K M) \rho_{w} g$.

2.3.2. Vertical Stress in the Confined Aquifer. For the sake of simplicity, it is assumed that primary consolidation in the confined aquifer occurs immediately after water head drawdown. The increased intergranular stress (also called the final effective stress increase) in the confined aquifer due to the single well pumping is equivalent to the additional
Increased pressure from overlain clay layer applied on the confined aquifer top surface due to a single well dewatering

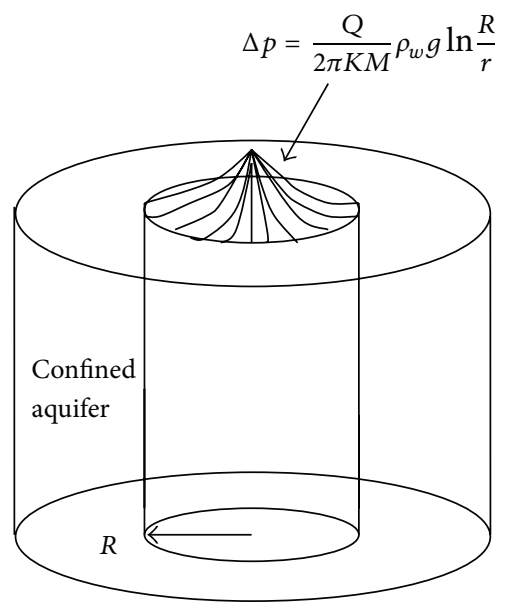

FIGURE 5: Increased pressures applied on the confined aquifer in a $3 \mathrm{D}$ view.

total stress acted on the soil particles (combination of soil skeleton and pore water), which can be determined with the Boussinesq solution if $E_{2}=E_{3}$ and $v_{2}=v_{3}$ in Figure 3.

The fundamental Boussinesq solution gives the vertical stress at point $(z, r)$ in the $z-r$ cylindrical coordinate system of Figure 4 as follows:

$$
\sigma_{z}=\frac{3}{2 \pi} \frac{1}{\left[1+(r / z)^{2}\right]^{5 / 2}} \frac{p}{z^{2}} .
$$

If the well radius is very small compared to the analysis region and can be assumed to be infinitely small for analysis simplification, with the external applied pressure on the confined aquifer top surface given in (7), the resultant vertical stress $\sigma_{z r}$ at $r=0$ at different depths $z$ can be approximated via the integral method:

$$
\sigma_{z r}=\int_{r_{w}}^{R} \frac{3 A}{z^{2}} \frac{r \ln (R / r)}{\left[1+(r / z)^{2}\right]^{5 / 2}} d r,
$$

where $A=(Q / 2 \pi K M) \rho_{w} g$, as defined above. As discussed above, $\sigma_{z r}$ is the additional total stress in the confined aquifer due to external applied pressure on the confined aquifer top surface given in (7) and is equal to the final effective stress increase.

\subsection{Primary Consolidation Settlement Calculation Theories}

2.4.1. Void Ratio Change and Intergranular Pressure. In the one-dimensional consolidation test, when the intergranular pressure increases from $p_{0}$ to $p_{0}+\sigma_{z r}$, according to the $e-\lg p$ curve and the definition of the compression index $C_{c}$, the void ratio change $\Delta e$ is calculated as follows [18]:

$$
\Delta e=e_{0}-e=C_{c} \lg \frac{p_{0}+\sigma_{z r}}{p_{0}}
$$

where $C_{c}$ is the compression index. 


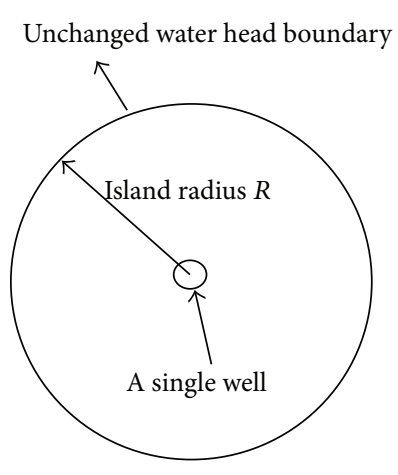

(a)

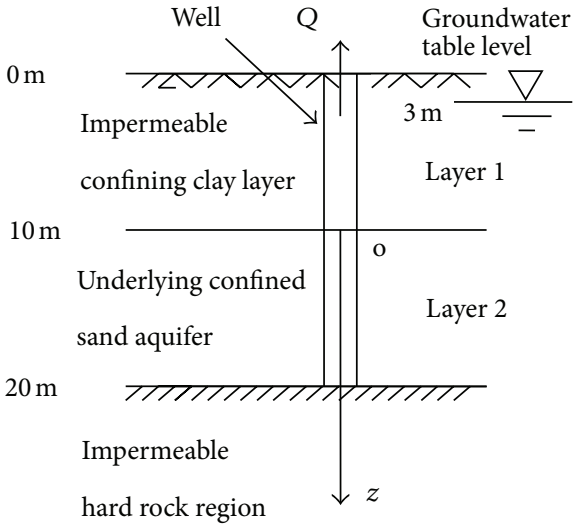

(b)

FIGURE 6: A single well pumping in an idealised island: (a) plan view; (b) sectional drawing.

2.4.2. Compacted Deformation in a Soil Layer with Thickness $d z$. In the one-dimensional consolidation test, the settlement $d \eta$ due to consolidation of a certain layer of thickness $d z$ because of a reduction in the void ratio from $e_{0}$ to $e$, in conjunction with an effective stress increase from $p_{0}$ to $p_{0}+$ $\sigma_{z r}$, can be derived from the following expression $[20,34]$ :

$$
d \eta=\frac{\Delta e}{1+e_{0}} d z=C_{c} \frac{1}{1+e_{0}} \lg \frac{p_{0}+\sigma_{z r}}{p_{0}} d z .
$$

2.4.3. Total Consolidation Settlement of the Confined Aquifer due to Single Well Pumping. The consolidation settlement of the confined sand aquifer at point $(0,0)$ in the $(r, z)$ coordinate system of Figure 4 is found from the summation of deformations in each layer of the confined aquifer with the integration method:

$$
\eta=\int_{0}^{D_{c}} d \eta=\int_{0}^{D_{c}} C_{c} \frac{1}{1+e_{0}(z)} \lg \frac{p_{0}+\sigma_{z r}}{p_{0}} d z .
$$

In the above equation, $C_{c}$ is the compression index, and $e_{0}(z)$ is the initial void ratio at depth $z$ in the midpoint of the $d \eta$ soil layer. Note that variable $D_{c}$ in Figure 3 is $M$ in Figure 2. Combine (5) and (9) and then (12) can be transformed as follows:

$$
\begin{gathered}
\eta=\int_{0}^{D_{c}} C_{c} \frac{1}{1+e_{0}(z)} \lg \left[\left(D \gamma_{1}+z \gamma_{2}-\left(H_{0}-D_{c}+z\right) \rho_{w} g\right.\right. \\
\left.\quad+\int_{r_{w}}^{R} \frac{3 A}{z^{2}} \frac{r \ln (R / r)}{\left[1+(r / z)^{2}\right]^{5 / 2}} d r\right) \\
\times\left(D \gamma_{1}+z \gamma_{2}-\left(H_{0}-D_{c}+z\right)\right. \\
\left.\left.\times \rho_{w} g\right)^{-1}\right] d z .
\end{gathered}
$$

The soil vertical compression strain at point $(0, z)$ derived from (11) is given as follows:

$$
\begin{gathered}
\varepsilon(0, z)=C_{c} \frac{1}{1+e_{0}} \lg \left[\left(D \gamma_{1}+z \gamma_{2}-\left(H_{0}-D_{c}+z\right) \rho_{w} g\right.\right. \\
\left.+\int_{r_{w}}^{R} \frac{3 A}{z^{2}} \frac{r \ln (R / r)}{\left[1+(r / z)^{2}\right]^{5 / 2}} d r\right) \\
\times\left(D \gamma_{1}+z \gamma_{2}-\left(H_{0}-D_{c}+z\right)\right. \\
\left.\left.\times \rho_{w} g\right)^{-1}\right] .
\end{gathered}
$$

\section{Validation of the Proposed Analytical Solution}

3.1. An Example. The radius of the single well in the idealised island in Figure 6 is 0.3 metres. The island radius $R$ as described in (1) is 100 metres. The overlying impermeable clay layer (layer 1) and confined sand aquifer (layer 2) are 10 metres each. The initial groundwater level is 17.0 metres as measured from the impermeable hard rock top surface. The soil properties in Figure 6 of the example are presented in Table 1. The compression index $C_{c}$ of the confined sand aquifer is 0.13 , while the initial void ratio $e_{0}$ is 0.6 .

After an extensive period of single well pumping with pumping rate $Q$ equal to approximately $0.00757 \mathrm{~m}^{3} / \mathrm{s}$, water flow is steady around the well, while the single well water level in Figure 6 decreases by 7 metres. The primary consolidation settlement at the single well due to well pumping in the confined sand aquifer is determined numerically and is presented analytically below. 
TABLE 1: Material properties of the soil layers in the example of Figure 6.

\begin{tabular}{lccccccc}
\hline $\begin{array}{l}\text { Layer } \\
\text { number }\end{array}$ & $\begin{array}{c}\text { Average unit } \\
\text { weight }\left(\mathrm{kN} / \mathrm{m}^{3}\right)\end{array}$ & $\begin{array}{c}\text { Elastic } \\
\text { modulus }(\mathrm{MPa})\end{array}$ & $\begin{array}{c}\text { Poisson's } \\
\text { ratio }\end{array}$ & $\begin{array}{c}\text { Cohesive } \\
\text { strength }(\mathrm{kPa})\end{array}$ & $\begin{array}{c}\text { Angle of internal } \\
\text { friction }\left(^{\circ}\right)\end{array}$ & $\begin{array}{c}\text { Horizontal hydraulic } \\
\text { conductivity } K_{h}(\mathrm{~m} / \mathrm{s})\end{array}$ & $\begin{array}{c}\text { Vertical hydraulic } \\
\text { conductivity } K_{v}(\mathrm{~m} / \mathrm{s})\end{array}$ \\
\hline 1 & 18.0 & 20 & 0.3 & 15 & 16 & $3.0 \times 10^{-9}$ & $5.0 \times 10^{-9}$ \\
2 & 20.0 & 40 & 0.22 & 2 & 31 & $1.0 \times 10^{-4}$ & $1.0 \times 10^{-4}$ \\
\hline
\end{tabular}

\subsection{Numerical Solution with ADINA}

3.2.1. Numerical Model Computing Region. A square region with side lengths of 200 metres is analysed in the numerical model and shown in Figure 7. In the following numerical simulation with the model built within ADINA, the influence radius of the single well in the square region of Figure 7 is approximately 98.3 metres, which is quite similar to the island radius $R$ in Figure 6. Therefore, the computational region selection of the square analysis region with side lengths of 200 metres in the numerical simulation produces negligible error regarding the settlement. In the ADINA computation process, the 20 metres depth soil layer in Figure 6(b) is divided into three layers as in Figure 7: the "waterless layer" (refers to the no water region) is 3.0 metres in depth, an "impermeable clay layer" is 7.0 metres in depth, and an "underlying confined sand aquifer layer" is 10.0 metres in depth.

The layers in Figure 7 are laterally constrained and are permeable in areas except for the rock bottom board. Neither displacements nor water flows at any direction are allowed at the rock bottom board. 3D element meshes of the porous media in the ADINA simulation process are generated and presented as in Figure 8.

3.2.2. Material Properties. The properties of the materials composing the "waterless" and "impermeable clay" layers in Figure 7 are all retrieved from the information on layer 1 in Table 1, with an exception that the "waterless" layer permeability is set as zero. The material properties of the "underlying confined sand" layer in Figure 7 are completely retrieved from the layer 2 information in Table 1.

The deformable continuous media material in the three soil layers as in Figure 7 is simulated with the Mohr-Coulomb model, which is based on linearly elastic and perfectly plastic yield behaviours. The yield function is defined by the MohrCoulomb criterion. The potential function is defined by the Drucker-Prager criterion. A piecewise tension cutoff analysis and a nonassociative flow rule are embedded in ADINA.

3.2.3. Computing Process with ADINA Software. The time step in the ADINA's computing is 0.1 day. The decrease of the water level in the single well totaled 7 metres, and the total computing time lasts for 108 days with 100 days for single well pumping and 8 days for stabilising the computed results. During pumping, the water level in the single well decreases by 0.07 metres per day.

3.2.4. Pore Pressures. Figure 9 gives the results of the excessive pore pressures around the well. From Figure 9, the maximum excessive pore pressure is $70000 \mathrm{~Pa}$ at the single well, which means that the water level of the single well in the confined aquifer decreases by approximately 7 metres. At the end of the computation, the influence radius in the computing region is approximately 98.3 metres, which is very close to 100 metres. Therefore, ADINA reasonably simulated the problem as in Figure 6.

3.2.5. Settlements. From Figure 10 and the resulting files from the ADINA software, the maximum settlements in all three soil layers in Figure 7 occur at the contact point between the "waterless" and "impermeable clay" layers with negligible deformation in the "waterless" layer. The maximum settlement of the confined sand aquifer occurs at the top surface of the confined sand aquifer at the single well. Its value is $70.43 \mathrm{~mm}$.

3.3. Proposed Analytical Solution. The proposed analytical solution mainly concerns the settlement of the confined sand aquifer (layer 2) in Figure 6 when water flow around the single well is steady, and the water level at the single well decreases by 7 metres. The total consolidated compressive deformation of layer 2 is determined with (14) using the parameters given in the example. The settlement results for different depth points in the confined aquifer at the single well are presented in Figure 11 for the analytical solution and ADINA. The maximum settlement of $76.8 \mathrm{~mm}$ in layer 2 at the single well in the top surface of layer 2 is similar to the $70.43 \mathrm{~mm}$ settlement calculated by ADINA. According to the detailed comparison between the proposed analytical solution and the numerical result obtained with the ADINA software in Figure 11, the settlements of layer 2 determined by the two methods are almost equal. Therefore, the proposed analytical solution is applicable under certain boundary conditions, as in the example in Figure 6. The excessive pore water pressures determined using ADINA and the proposed analytical solution are presented in Figure 12. It is obvious that they almost coincide with each other. The deformation of the impermeable clay layer (layer 1, which includes "waterless" and "impermeable clay" layers) in Figure 6 is not presented in the analytical solution.

\section{Case Study}

The settlement prediction of the fourth confined sand aquifer in Shanghai city is performed with the above-proposed analytical solution. The detailed process is as follows.

4.1. Study Area. As the country's most densely populated and developed area, Shanghai city encounters land subsidence problems due to well pumping. Many large residential districts and business firms are located in Shanghai, and there is an extensive groundwater exploitation in this area. When 


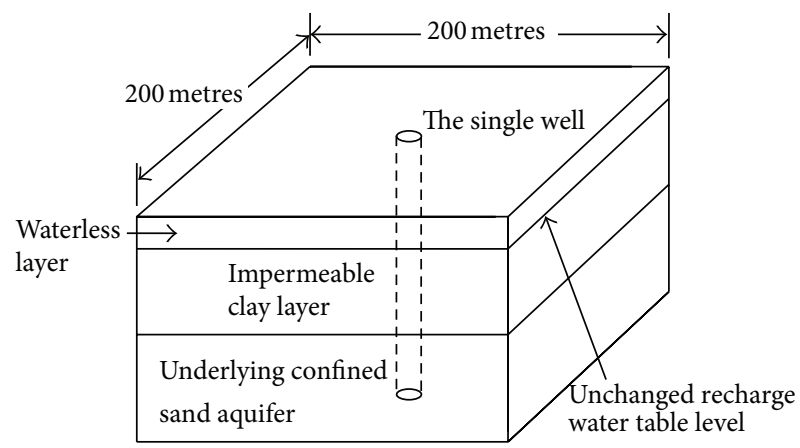

Rock bottom board

Figure 7: Analysis region in ADINA.

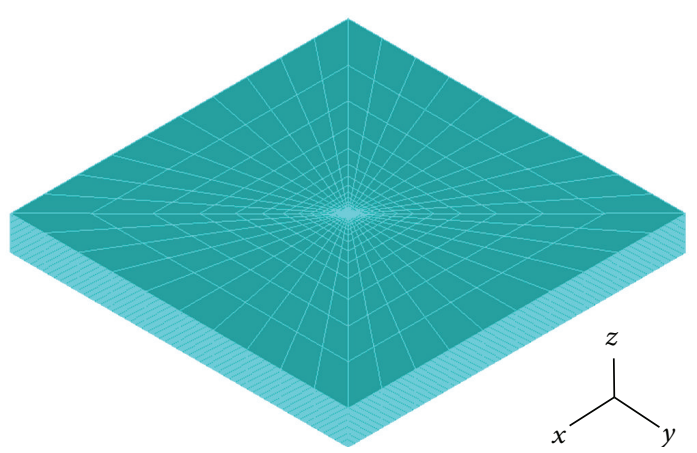

Figure 8: Mesh generation with ADINA.

groundwater is extracted at a constant rate in Pudong New Area of Shanghai, the study area can be recharged with water from the Huangpu River, Yellow Sea, and East China Sea, as shown in Figure 13. A balance can exist between the confined aquifer and the supply water system after some time for given pumping conditions (e.g., pumping rate, well radius, etc.).

A sectional drawing of the corresponding earth layer is shown in Figure 14(a). Before the 1980s, the Shanghai second and third confined sand aquifers were the main groundwater extraction layers [25]. Since the 1980s, the fourth confined aquifer has been the main confined aquifer for groundwater extraction. From 1980 to 1995, the fourth confined aquifer contributed a total settlement of approximately $30 \mathrm{~mm}$ to the total subsidence $[24,25]$.

Because the fourth confined aquifer is mainly composed of sand and has been the main confined aquifer for groundwater extraction since the 1980s, the fourth confined aquifer is isolated as the research layer, as shown in Figure 14(b). In the analytical solution, the earth layers (layers with a depth of less than 160 metres) above the roof of the fourth confined aquifer and the earth layers (layers with a depth greater than 240 metres) below the floor of the fourth confined aquifer are all equivalently transformed to impermeable layers in Figure 14(b).

The fourth confined sand aquifer, shown in Figure 14, is fully penetrated by a single well and generates consolidation settlement as a result of single well pumping. As water flows
TABLE 2: Upper confining clay layer parameters in the settlement simulation.

\begin{tabular}{lccc}
\hline $\begin{array}{l}\text { Earth layer } \\
\text { name }\end{array}$ & $\begin{array}{c}\text { Thickness } \\
D(\mathrm{~m})\end{array}$ & $\begin{array}{c}\text { Average unit } \\
\text { weight } \gamma_{1}\left(\mathrm{kN} / \mathrm{m}^{3}\right)\end{array}$ & $\begin{array}{c}\text { Initial ground } \\
\text { water level } H_{0}(\mathrm{~m})\end{array}$ \\
\hline $\begin{array}{l}\text { Confining } \\
\text { impermeable } \\
\text { layer }\end{array}$ & 160 & 18.0 & 228 \\
\hline
\end{tabular}

into the well at a constant rate, equations (1), (2), (3), and the proposed analytical solution can be applied to the settlement simulation of the fourth confined aquifer of Shanghai.

4.2. Parameters Adopted for the Proposed Analytical Solution. The pumping well radius $r_{w}$ in this study is 0.3 metres with a pumping rate $Q$ of $0.121 \mathrm{~m}^{3} / \mathrm{s}$ [35]. From 1980 to 1995 , the water head drawdown $s_{w}$ at the well was approximately 18 metres [24, 25]. The Shanghai ground height above sea level is approximately 2 metres. The soil parameters are presented in Tables 2 and 3 [24, 25, 36].

According to the Sichardt equation, the influence radius $R$ of Figures 4 and 5 for the pumping well in this case study can be determined empirically as $R=540$ metres [32]. $A$ in (9) for the settlement simulation is determined to be $24014 \mathrm{~Pa}$.

\subsection{Predictions}

4.3.1. Vertical Compression Stress in the Fourth Confined Sand Aquifer of Shanghai. In the proposed analytical solution, the resultant vertical stress $\sigma_{z r}$ at $r=0$ induced by single well pumping and the consequent pressure from the overlying impermeable layer is determined by (9). After substituting the parameters in the above example for the settlement simulation of the fourth confined aquifer of Shanghai, the results are presented in Figure 15. First, $\sigma_{z r}$ increases and then decreases. Its maximum value is reached when the soil layer depth is approximately 161 metres, measured from the ground downwards, as shown in Figure 14(b). The fourth confined sand aquifer of Shanghai consolidates immediately after its water is extracted during single well pumping. Here, $\sigma_{z r}$ is the final effective stress increase in the fourth confined aquifer of Shanghai at the point $r=0$ as determined by (9). 

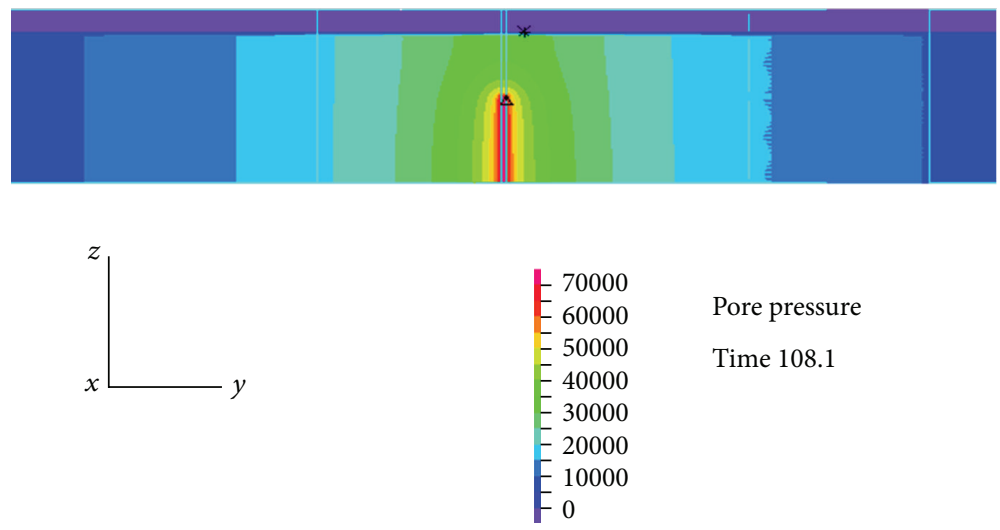

FIGURE 9: Pore pressures analysed with the ADINA software.

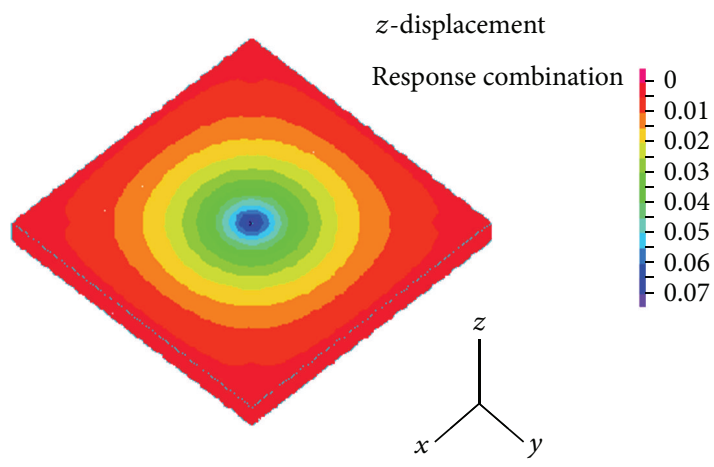

(a)

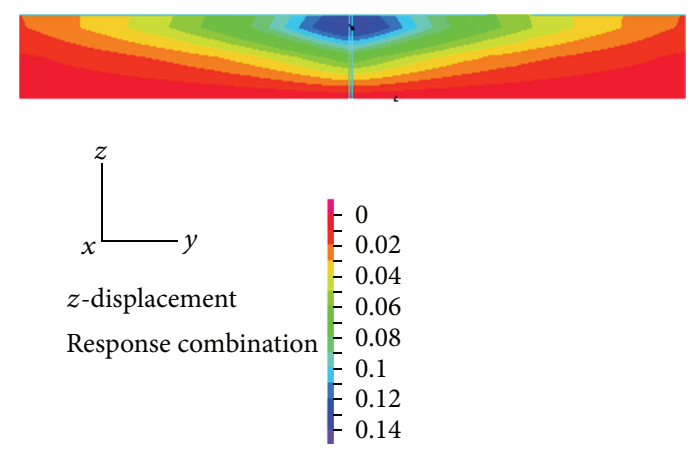

(b)

FIGURE 10: Settlements analysed with the ADINA software: (a) three-dimensional view of layer 2; (b) sectional drawing of layer 1 and layer 2.

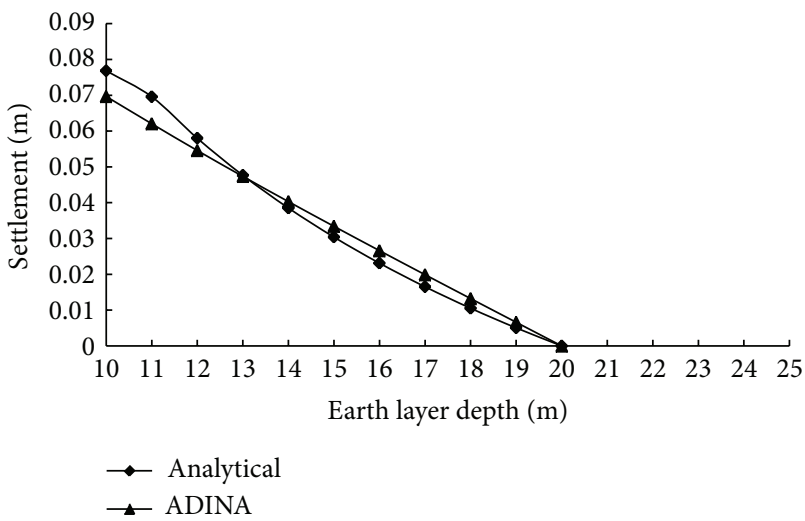

FIGURE 11: Settlements of different depth points in the underlying confined sand aquifer (layer 2) at the single well.

4.3.2. Vertical Compression Strain in the Fourth Confined Sand Aquifer of Shanghai. The vertical compression strain $\varepsilon(0, z)$ is determined using (14). The soil vertical compression strain $\varepsilon(0, z)$ at point $(0, z)$ is presented in Figure 16. First, $\varepsilon(0, z)$ increases, and then it decreases. Its maximum value is reached when the soil layer depth is approximately 161 metres measured from the ground downwards, as shown in Figure 14(b).

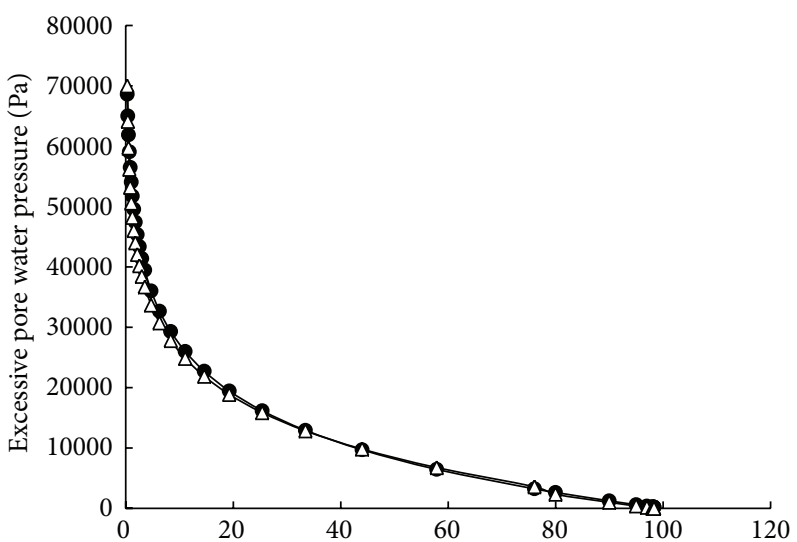

Horizontal distance from the single well to the analysis point $(\mathrm{m})$

$$
\rightarrow \text { Analytical }
$$$$
\triangle \text { Adina }
$$

FIGURE 12: Excessive pore water pressures at the analysis points at different distances to the single well in the centre of the horizontal radial plane.

4.3.3. Prediction of the Consolidation Settlement of the Fourth Confined Sand Aquifer of Shanghai. According to (13), the primary consolidation settlement of the fourth confined sand 


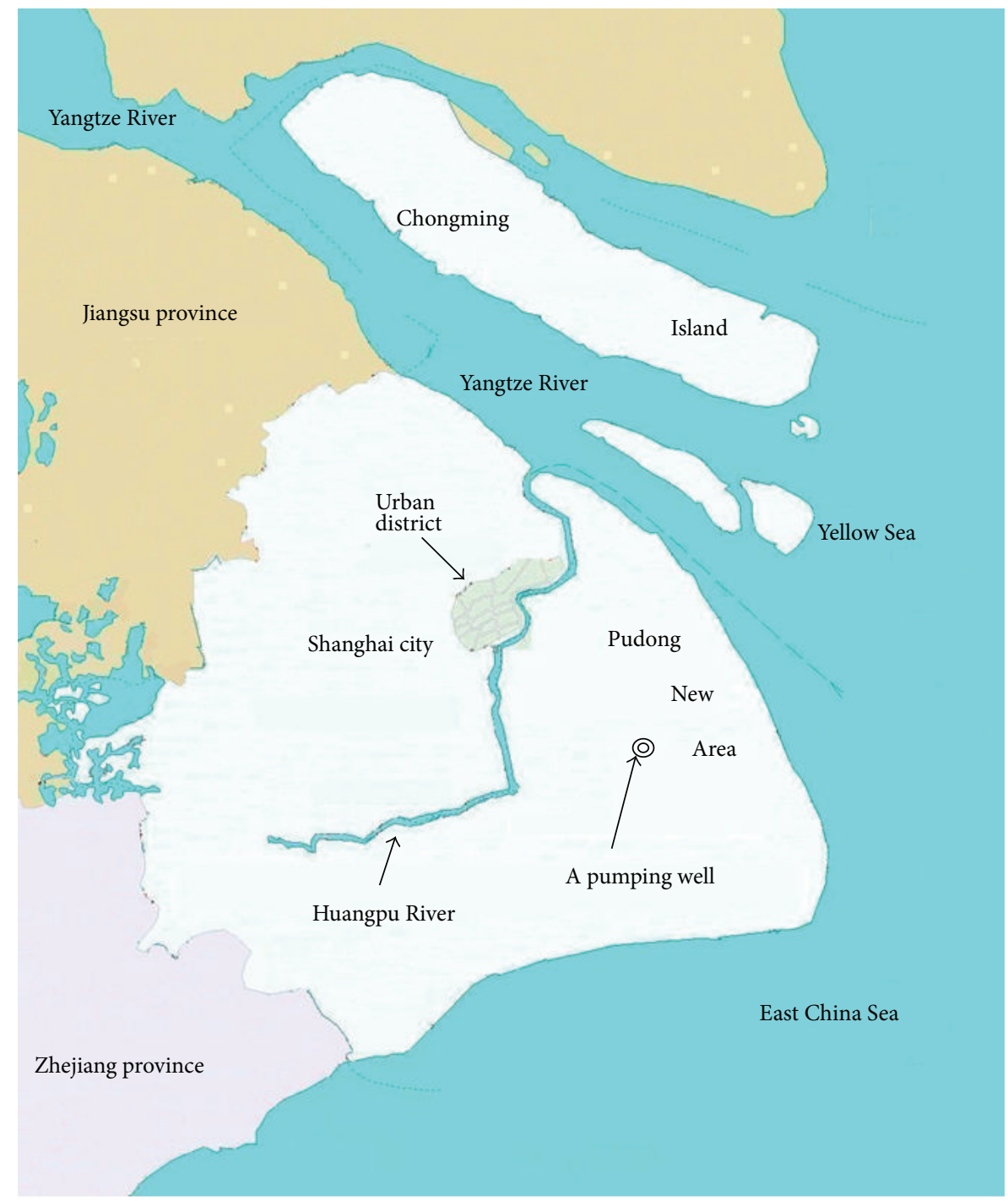

Figure 13: The Pudong New Area of Shanghai city as a case study.

TABLE 3: Fourth confined sand aquifer parameters in the settlement simulation.

\begin{tabular}{lcccc}
\hline Earth layer name & $\begin{array}{c}\text { Compression } \\
\text { index } C_{c}\end{array}$ & $\begin{array}{c}\text { Thickness } \\
M=D_{c}(\mathrm{~m})\end{array}$ & $\begin{array}{c}\text { Saturated sand unit } \\
\text { weight } \gamma_{2}\left(\mathrm{kN} / \mathrm{m}^{3}\right)\end{array}$ & $\begin{array}{c}\text { Hydraulic } \\
\text { conductivity } K(\mathrm{~m} / \mathrm{s})\end{array}$ \\
\hline $\begin{array}{l}\text { Fourth confined sand } \\
\text { aquifer }\end{array}$ & 0.05 & 80 & 20.0 & $1.0 \times 10^{-4}$ \\
\hline
\end{tabular}

aquifer of Shanghai at the single well due to single pumping can be determined via the numerical integration method. The derived values for the proposed analytical solution were presented in Figure 17, and the maximum settlement is $41.5 \mathrm{~mm}$. Only the subsidence induced by the compression of the fourth confined aquifer is included in the proposed analytical solution because the fourth confined aquifer has been the main confined aquifer for groundwater extraction since the 1980s [25].
4.4. Comparing the Fourth Confined Aquifer Predicted Settlement with In Situ Measured Values. Seepage monitoring records are presented in Figure 18 according to reference [23]. The deformation-groundwater level ( $\mathrm{m}$ above sea level) in the fourth confined aquifer according to $\mathrm{Wu}$ et al. is presented in Figure 19 [24]. According to $\mathrm{Wu}$ et al. [24] and Wei et al. [25], from 1980 to 1995, there was a total settlement of approximately $30 \mathrm{~mm}$ contributed by the fourth confined aquifer. The maximum subsidence of $41.5 \mathrm{~mm}$ at 


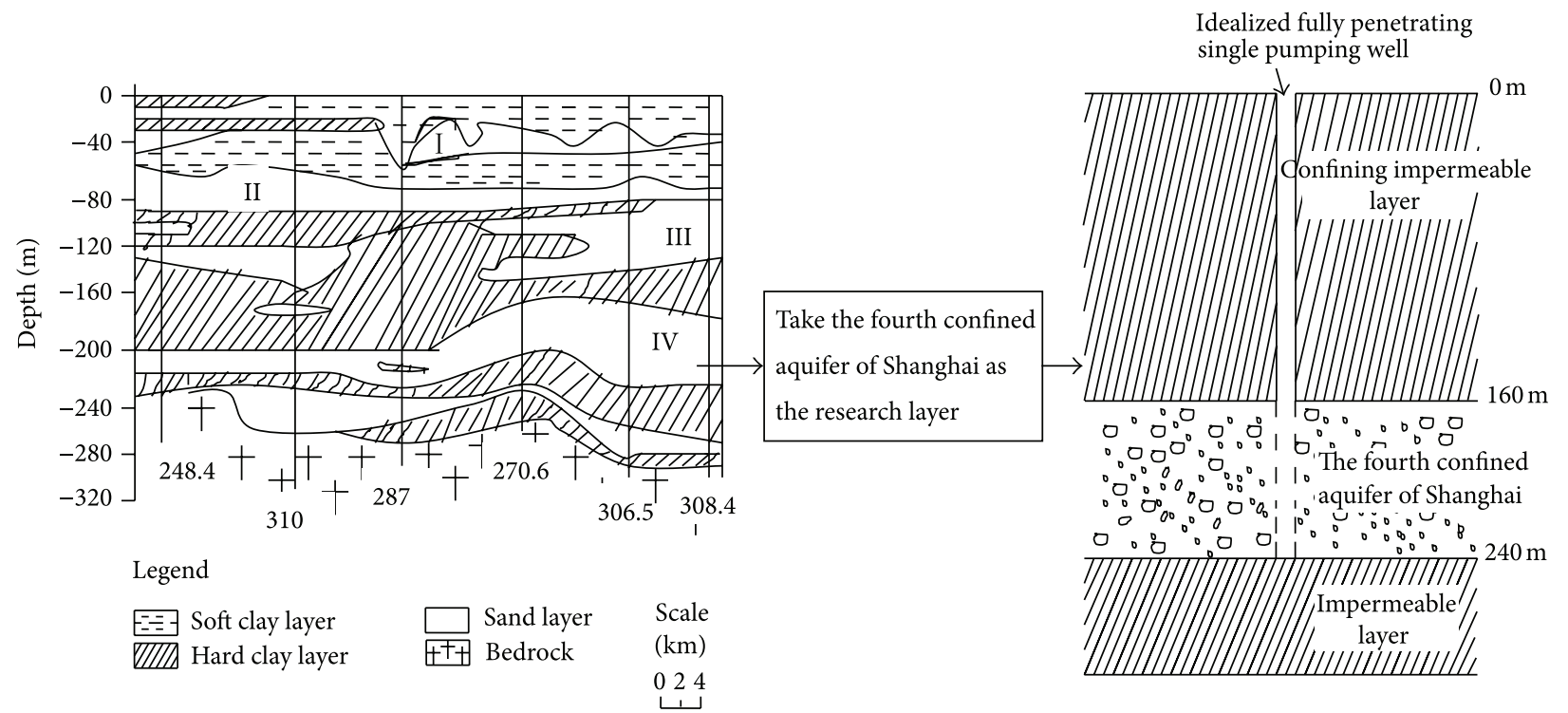

(a)

(b)

FIGURE 14: (a) Shanghai quaternary period earth layer characteristics where I, II, III, and IV are the first, second, third, and fourth confined aquifers of Shanghai, respectively. (b) The fourth confined aquifer as the research layer in the analytical solution.

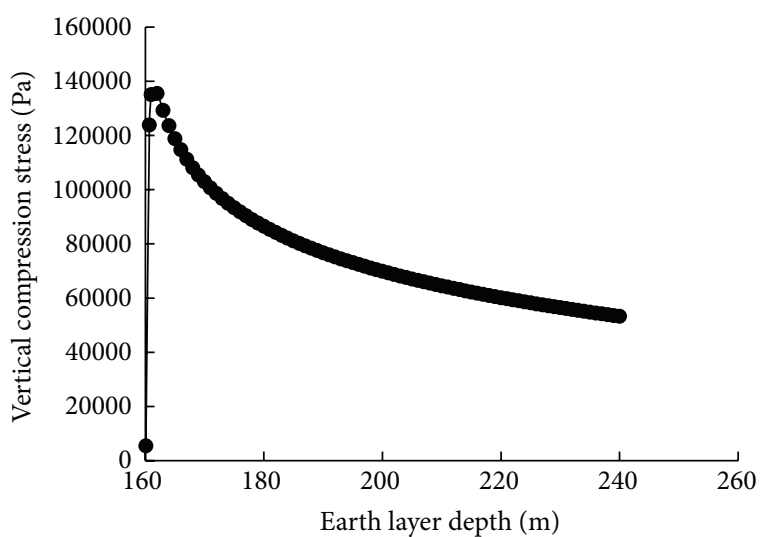

FIGURE 15: Vertical compression stress in the fourth confined sand aquifer of Shanghai.

the Shanghai's fourth confined aquifer from 1980 to 1995 predicted with the analytical solution (13) is very close to the in situ measurements of Wu et al. [24] and Wei et al. [25].

\section{Discussion}

5.1. Assumptions in the Theory of the Proposed Analytical Solution. If the influence radius $R$ shown in Figure 2 is difficult to determine in practical situations, the Sichardt equation can be used to determine $R$ empirically [32]. In order to use (1) or, consequently, (6), the condition $s_{w} \leq H_{0}-D_{c}$ must be satisfied. Equation (8) is the basic Boussinesq solution, which can only be used if $E_{2}=E_{3}$ and $v_{2}=v_{3}$ and the single well radius remains infinitely small. The proposed analytical solution is fundamentally applicable for the

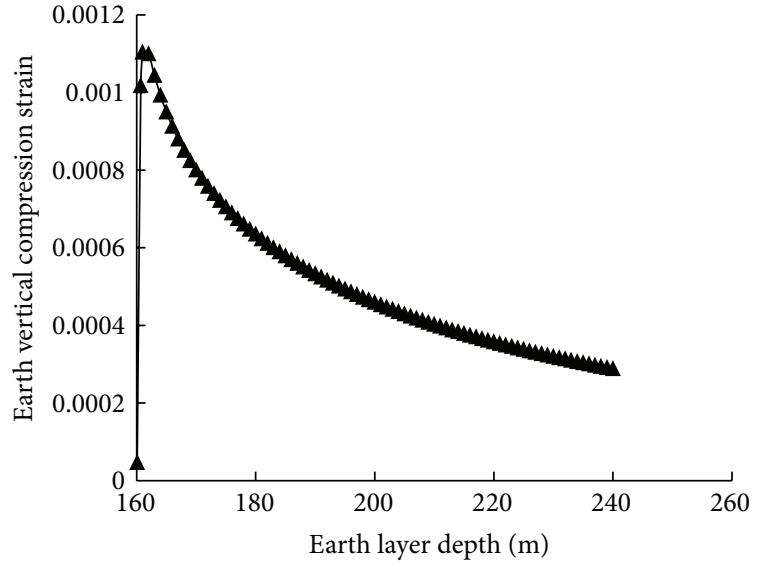

FIGURE 16: Vertical compression strain in the fourth confined sand aquifer of Shanghai at the single well.

proposed analytical solution for the use in the prediction of the fourth confined aquifer of Shanghai.

This paper does not incorporate the Terzaghi equation or the Biot equation in the prediction process because the Terzaghi equation and the Biot equation are mainly intended to predict pore water pressure and the corresponding consolidation degree for low permeability soils. However, the confined aquifer is composed of sand, and sand aquifers consolidate immediately after water extraction.

5.2. Limits of the Present Analytical Solution and Possible Future Modifications for the Prediction of Consolidation Settlement. Equation (10) implies the following:

$$
\Delta u=\Delta \sigma_{1}=\sigma_{z}
$$




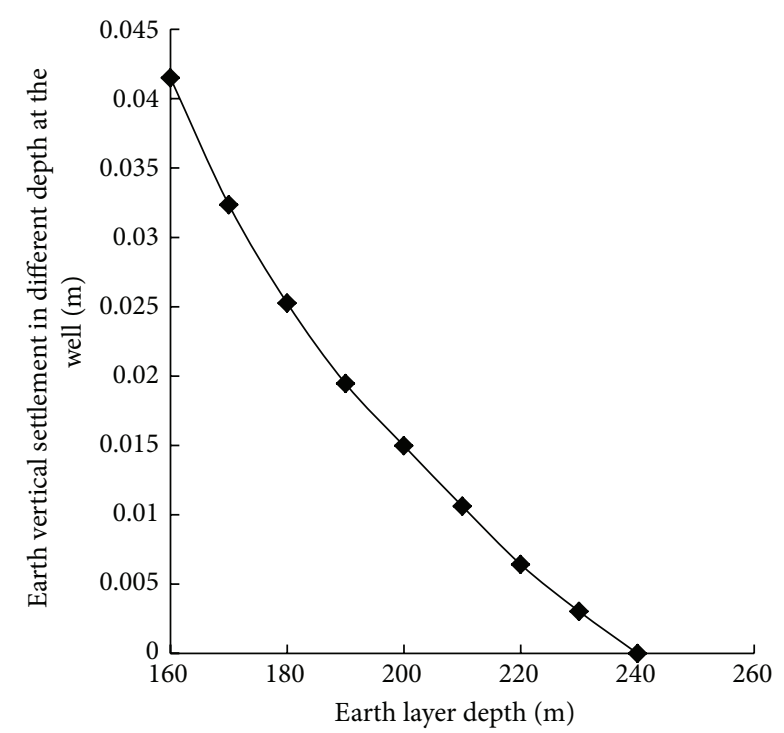

Figure 17: Total settlements of different depth points in the Shanghai fourth confined sand aquifer at the single well from 1980 to 1995.

$\Delta \mathcal{u}, \Delta \sigma_{1}$, and $\sigma_{z}$ are physical quantities representing the physical process of the one-dimensional consolidation test where the external compressive load is exerted vertically and axially. The soil sample for test is saturated. $\sigma_{z}$ is the vertical axial additional total stress acting on the soil particles in the soil sample due to the vertical external compressive load. $\Delta u$ denotes the initial excess pore water pressure induced by vertical axial external load. $\Delta \sigma_{1}$ is the intergranular vertical pressure increase (also called the final vertical effective stress increase) because the overall dissipation of the initial excess pore water pressure $\Delta u$ after primary consolidation is completed. This equation is only accurate for the one-dimensional consolidation test where there is no lateral yielding of the soil specimen and the ratio of the minor to major principal effective stresses, $K_{0}$, remains constant [34].

Skempton and Bjerrum gave the final vertical compression of a soil element of thickness $d z$ caused by the initial generated and final completed dissipation of excess pore water pressure where the soil element is substantial in triaxial compression tests (e.g., soil triaxial shear test $[37,38]$ ). The initial excess pore water pressure is obtained from a threedimensional analysis, while the consolidation settlement due to completed dissipation of excess pore water pressure is determined according to the void ratio pressure curve in the one-dimensional consolidation test. In the one-dimensional consolidation test, the soil specimen is restrained laterally and loaded vertically axially. The equation by Skempton and Bjerrum is as follows:

$$
d S_{c}=\left(\frac{1}{E s}\right) \Delta \sigma_{1}\left[B+\frac{\Delta \sigma_{3}}{\Delta \sigma_{1}}(1-B)\right] d z,
$$

$d S_{c}$ denotes the vertical axial consolidation settlement when the soil sample in the experiment is in triaxial compression (i.e., soil triaxial shear test), Es is the soil compression modulus when the soil specimen is restrained laterally and loaded

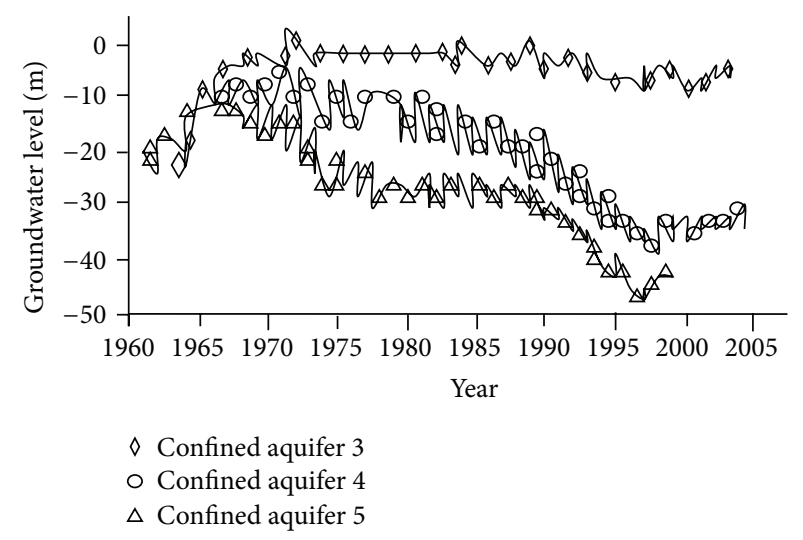

FIGURE 18: History of the groundwater level ( $m$ above sea level) for the confined aquifers in Shanghai [23].

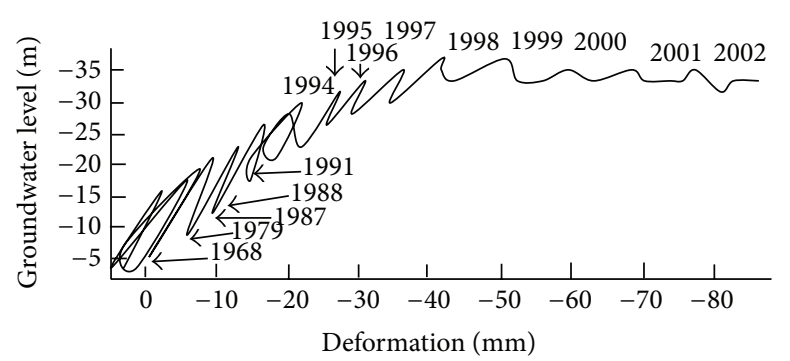

Figure 19: Deformation-groundwater level (m above sea level) curve of the fourth confined aquifer in Shanghai [24].

vertically axially in the one-dimensional consolidation test, $\Delta \sigma_{1}$ is the vertical axial stress increase in the soil specimen (in the soil triaxial shear test), $\Delta \sigma_{3}$ is the horizontal stress increase in the soil specimen (in the soil triaxial shear test), and $B$ is the pore-pressure coefficient under differential stress $\left(\Delta \sigma_{1}-\Delta \sigma_{3}\right)$.

This analysis suggests that (10) and the derived analytical solution (13) are just approximate solutions and could be improved with (16) to include the influence of triaxial stress on the initial excess pore water pressure. It means that $\sigma_{z r}$ is not the final effective stress increase in the Skempton and Bjerrum theory. The final effective stress increase should be determined with three-dimensional stress analysis with the Boussinesq solution, consequent principle stress analysis and that soil triaxial shear test. This point could be improved in the future.

\section{Conclusions}

This paper proposes a simplified analytical solution for determining the primary consolidation settlement of a confined sand aquifer overlain by an impermeable clay layer at the single well induced by single well pumping in a confined sand aquifer. For the sand aquifer, because the initial immediate settlement occurs before pumping, and the secondary compression is usually negligible, primary consolidation settlement can be regarded as the final settlement. 
The method is constituted by a series of fundamental equations. First, with an assumption of steady state, axisymmetric drawdown around a single well, the radial water head drawdown is predicted with the Dupuit equation. Then, the confining pressure on the underlain confined aquifer is determined with the assumption that the loss of confined aquifer water head against the upper confining impermeable layer converts to equivalent confining pressure according to the principles of equilibrium of forces in the vertical direction. With the obtained confining pressure on the underlain confined aquifer, the vertical additional stress in the confined aquifer is computed using the Boussinesq solution. After that, the void ratio change under the vertical stress is determined by the compression index from the $e-\lg p$ curve from a onedimensional consolidation test. Then, the vertical strain of soil can be obtained. The consolidation deformation of the vertical element layer in the aquifer is then derived using the strain and the element layer thickness. With the integral method, the overall consolidation settlement, which is the sum of the settlements of all vertical element layers, can be obtained. Validation of the proposed analytical solution with the ADINA software is presented as an example. The analytical solution is found to be applicable and cost-effective in predicting the settlement of a confined sand aquifer overlain by an impermeable clay layer.

The proposed analytical solution is then used to predict the fourth confined sand aquifer settlement due to water head drawdown in the Pudong New Area of Shanghai. The predicted value of $41.5 \mathrm{~mm}$ calculated using the proposed analytical solution in (13) is close to the in situ measured settlement of $30 \mathrm{~mm}$ for the fourth confined aquifer of Shanghai due to water extraction from 1980 to 1995 , according to the measurements of Wu et al. [24] and Wei et al. [25].

\section{Conflict of Interests}

The authors declare that they have no financial and personal relationships with other people or organisations that could inappropriately influence their work. The authors of this paper have chosen not to furnish the paper and its readers with information that might present a potential conflict of interests.

\section{Acknowledgments}

The first author was supported by the 47th Chinese Postdoctoral Scientific Fund (no. 113000-X91001) and is supported by the Scientific Research Starting Funds at Liaoning Technical University (no. 11-415). The second author is supported by the National Natural Science Foundation of China (no. 51079127, no. 51179171, and no. 51279180). Comments from the reviewers are greatly appreciated.

\section{References}

[1] M. Budhu and I. B. Adiyaman, "Mechanics of land subsidence due to groundwater pumping," International Journal for Numerical and Analytical Methods in Geomechanics, vol. 34, no. 14, pp. 1459-1478, 2010.
[2] R. L. Hu, Z. Q. Yue, L. C. Wang, and S. J. Wang, "Review on current status and challenging issues of land subsidence in China," Engineering Geology, vol. 76, no. 1-2, pp. 65-77, 2004.

[3] J. H. Kihm, J. M. Kim, S. H. Song, and G. S. Lee, “Three-dimensional numerical simulation of fully coupled groundwater flow and land deformation due to groundwater pumping in an unsaturated fluvial aquifer system," Journal of Hydrology, vol. 335, no. 1-2, pp. 1-14, 2007.

[4] A. I. Calderhead, R. Therrien, A. Rivera, R. Martel, and J. Garfias, "Simulating pumping-induced regional land subsidence with the use of InSAR and field data in the Toluca Valley, Mexico," Advances in Water Resources, vol. 34, no. 1, pp. 83-97, 2011.

[5] X. Shi, J. Wu, S. Ye et al., "Regional land subsidence simulation in Su-Xi-Chang area and Shanghai City, China," Engineering Geology, vol. 100, no. 1-2, pp. 27-42, 2008.

[6] A. M. Wilson and S. Gorelick, "The effects of pulsed pumping on land subsidence in the Santa Clara Valley, California," Journal of Hydrology, vol. 174, no. 3-4, pp. 375-396, 1996.

[7] O. J. Santos Jr. and T. B. Celestino, "Artificial neural networks analysis of São Paulo subway tunnel settlement data," Tunnelling and Underground Space Technology, vol. 23, no. 5, pp. 481-491, 2008.

[8] C. Chen, S. Pei, and J. J. Jiao, "Land subsidence caused by groundwater exploitation in Suzhou City, China," Hydrogeology Journal, vol. 11, no. 2, pp. 275-287, 2003.

[9] J. Hoffmann, D. L. Galloway, and H. A. Zebker, "Inverse modeling of interbed storage parameters using land subsidence observations, Antelope Valley, California," Water Resources Research, vol. 39, no. 2, p. 1231, 2003.

[10] D. Bernaud, L. Dormieux, and S. Maghous, "A constitutive and numerical model for mechanical compaction in sedimentary basins," Computers and Geotechnics, vol. 33, no. 6-7, pp. 316-329, 2006.

[11] Y. Liu and D. C. Helm, "Inverse procedure for calibrating parameters that control land subsidence caused by subsurface fluid withdrawal: 1. Methods," Water Resources Research, vol. 44, no. 7, pp. 1-15, 2008.

[12] T. Keller, M. Lamande, S. Peth et al., "An interdisciplinary approach towards improved understanding of soil deformation during compaction," Soil \& Tillage Research, vol. 128, pp. 61-80, 2013.

[13] T. J. Burbey, "Stress-strain analyses for aquifer-system characterization," Ground Water, vol. 39, no. 1, pp. 128-136, 2001.

[14] T. J. Burbey, "Use of vertical and horizontal deformation data with inverse models to quantify parameters during aquifer testing," in Proceedings of the 7th International Symposium on Land Subsidence, Shanghai, China, 2005.

[15] D. L. Rudolph and E. O. Frind, "Hydraulic response of highly compressible aquitards during consolidation," Water Resources Research, vol. 27, no. 1, pp. 17-30, 1991.

[16] S. A. Leake and D. L. Galloway, MODFLOW Ground-Water Model-User Guide to the Subsidence and Aquifer-System Compaction Package (SUB-WT) for Watertable Aquifers, Techniques and Methods 6-A23, US. Geological Survey, 2007.

[17] S. Q. Wang, Y. P. Wee, and G. Ofori, "DSSDSS: a decision support system for dewatering systems selection," Building and Environment, vol. 37, no. 6, pp. 625-645, 2002.

[18] H. Bouwer, "Land subsidence and cracking due to ground-water depletion," Ground Water, vol. 15, no. 5, pp. 358-364, 1977. 
[19] H. Sun, D. Grandstaff, and R. Shagam, "Land subsidence due to groundwater withdrawal: potential damage of subsidence and sea level rise in southern New Jersey, USA," Environmental Geology, vol. 37, no. 4, pp. 290-296, 1999.

[20] C. Chen, S. Pei, and J. J. Jiao, "Land subsidence caused by groundwater exploitation in Suzhou City, China," Hydrogeology Journal, vol. 11, no. 2, pp. 275-287, 2003.

[21] D. Roy and K. E. Robinson, "Surface settlements at a soft soil site due to bedrock dewatering," Engineering Geology, vol. 107, no. 3-4, pp. 109-117, 2009.

[22] C. Li, X. Tang, and T. Ma, "Land subsidence caused by groundwater exploitation in the Hangzhou-Jiaxing-Huzhou plain, China," Hydrogeology Journal, vol. 14, no. 8, pp. 1652-1665, 2006.

[23] X. Shi, Y. Xue, J. Wu et al., "Characterization of regional land subsidence in Yangtze Delta, China: the example of Su-XiChang area and the city of Shanghai," Hydrogeology Journal, vol. 16, no. 3, pp. 593-607, 2008.

[24] J. Wu, X. Shi, S. Ye et al., "Numerical simulation of viscoelastoplastic land subsidence due to groundwater overdrafting in shanghai, China," Journal of Hydrologic Engineering, vol. 15, no. 3, pp. 223-236, 2010.

[25] Z. X. Wei, G. F. Yang, and J. Y. Yu, "Stress-strain characteristic of the confined aquifer system and land subsidence controlling countermeasures in Shanghai," The Chinese Journal of Geological Hazard and Control, vol. 16, no. 1, pp. 5-8, 2005 (Chinese).

[26] S. van Asselen, E. Stouthamer, and T. W. J. van Asch, "Effects of peat compaction on delta evolution: a review on processes, responses, measuring and modeling," Earth-Science Reviews, vol. 92, no. 1-2, pp. 35-51, 2009.

[27] A. S. Gregory, W. R. Whalley, C. W. Watts, N. R. A. Bird, P. D. Hallett, and A. P. Whitmore, "Calculation of the compression index and precompression stress from soil compression test data," Soil and Tillage Research, vol. 89, no. 1, pp. 45-57, 2006.

[28] S. Silliman and D. Higgins, "An analytical solution for steadystate flow between aquifers through an open well," Ground Water, vol. 28, no. 2, pp. 184-190, 1990.

[29] M. Bakker and K. Hemker, "A Dupuit formulation for flow in layered, anisotropic aquifers," Advances in Water Resources, vol. 25, no. 7, pp. 747-754, 2002.

[30] M. Bakker, "Simulating groundwater flow in multi-aquifer systems with analytical and numerical Dupuit-models," Journal of Hydrology, vol. 222, no. 1-4, pp. 55-64, 1999.

[31] M. Li, N. R. Diao, and Z. H. Fang, "Analysis of seepage flow in a confined aquifer with a standing column well," Journal of Hydrodynamics, vol. 19, no. 1, pp. 84-91, 2007.

[32] D. Bloomquist, A. A. Viala, and M. Gartner, Development of a Field Permeability Apparatus: The Vertical And Horizontal Insitu Permeameter (VAHIP), Department of Civil and Coastal Engineering, University of Florida, Gainesville, Fla, USA, 2007.

[33] W. J. Niu, "An approximated analytical solution to the problem of single well pumping within an irregular boundary," in Proceedings of the Civil Engineering and Urban Planning (ASCE '12), pp. 88-92, Yantai, China, 2012.

[34] M. M. Monkul and O. Önal, "A Visual Basic program for analyzing oedometer test results and evaluating intergranular void ratio," Computers and Geosciences, vol. 32, no. 5, pp. 696-703, 2006.

[35] Z. W. Li, Y. Zhang, and C. L. Chen, "Disposal for pumping well in phreatic water aquifer in three-dimensional numerical simulaion," Journal of Water Resources and Architectural Engineering, vol. 6, no. 2, pp. 121-126, 2008 (Chinese).
[36] Y. S. Xu, S. L. Shen, C. P. Tang, and H. Jiang, "Three-dimensional analysis of land subsidence based on groundwater flow model," Rock and Soil Mechanics, vol. 26, pp. 109-112, 2005 (Chinese).

[37] C. B. Zhanga, L. H. Chena, and Y. P. Liu, “Triaxial compression test of soil-root composites to evaluate influence of roots on soil shear strength," Ecological Engineering, vol. 36, pp. 19-26, 2010.

[38] S. J. Lee, Y. M. A. Hashash, and E. G. Nezami, "Simulation of triaxial compression tests with polyhedral discrete elements," Computers and Geotechnics, vol. 43, pp. 92-100, 2012. 


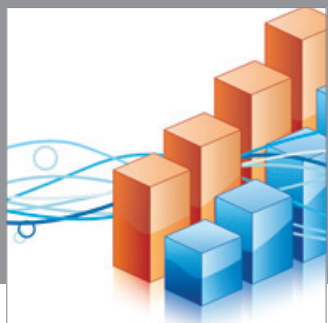

Advances in

Operations Research

mansans

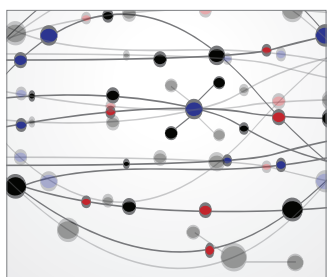

The Scientific World Journal
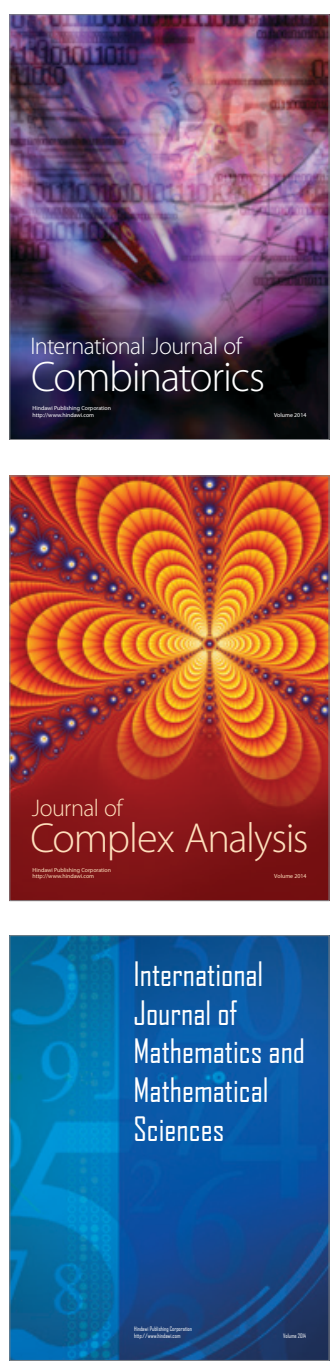
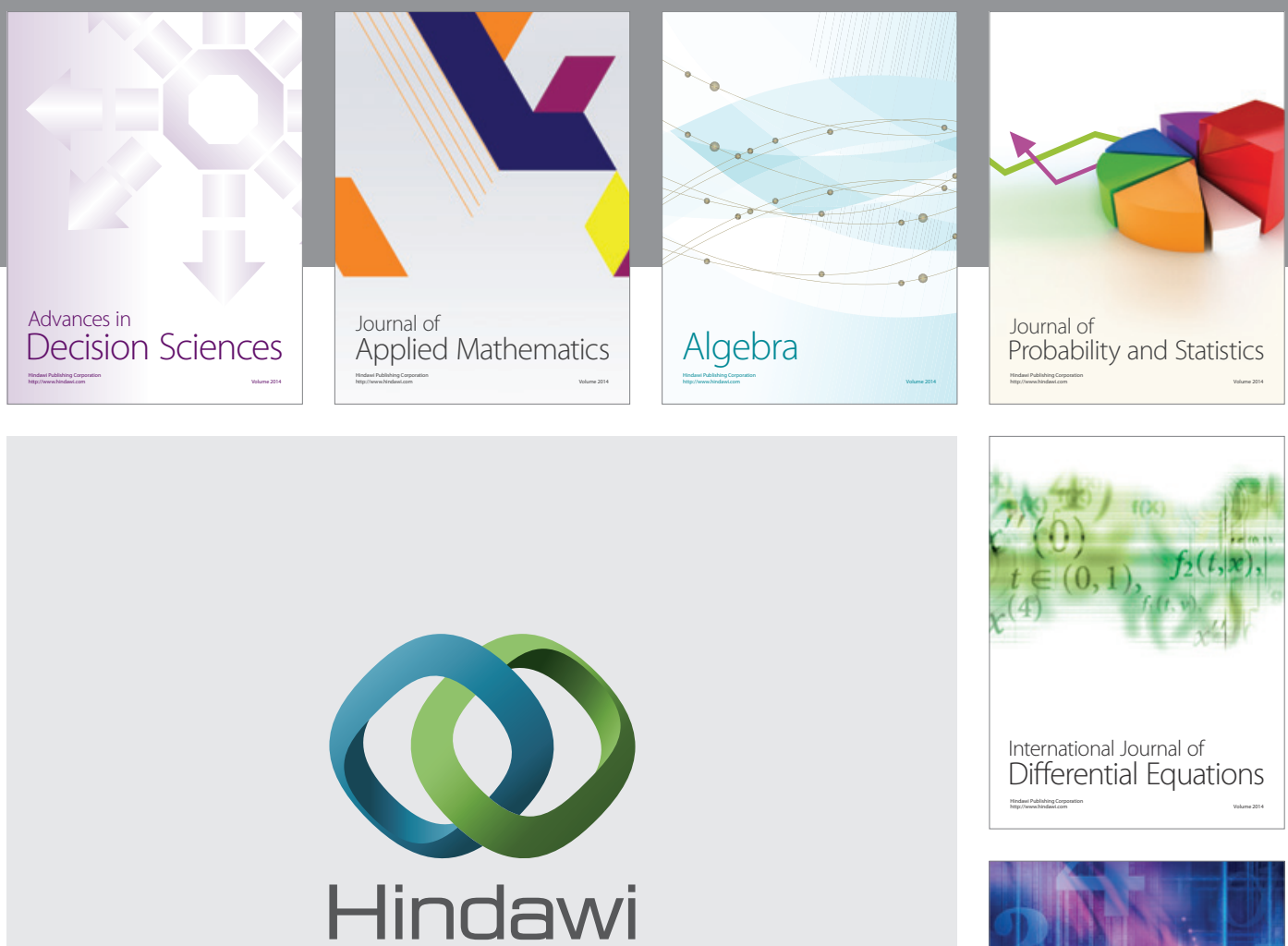

Submit your manuscripts at http://www.hindawi.com
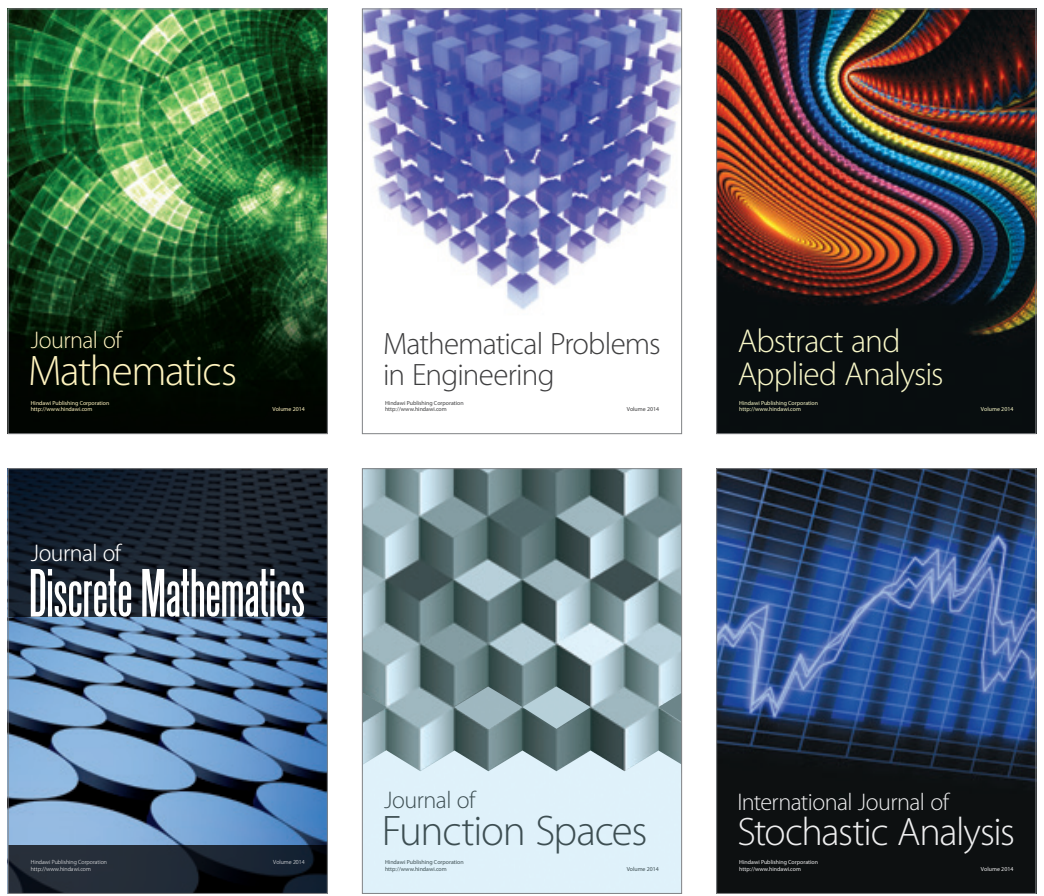

Journal of

Function Spaces

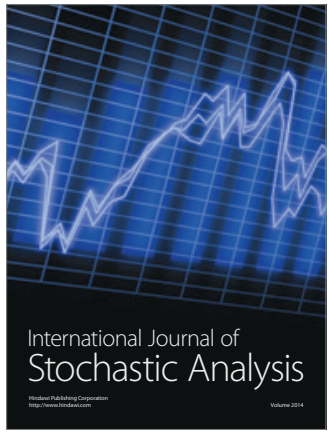

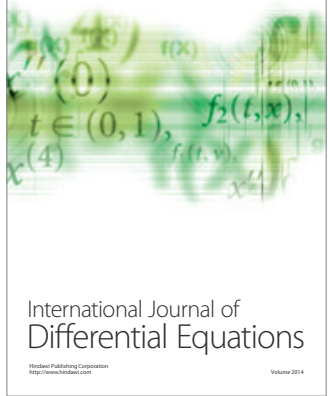
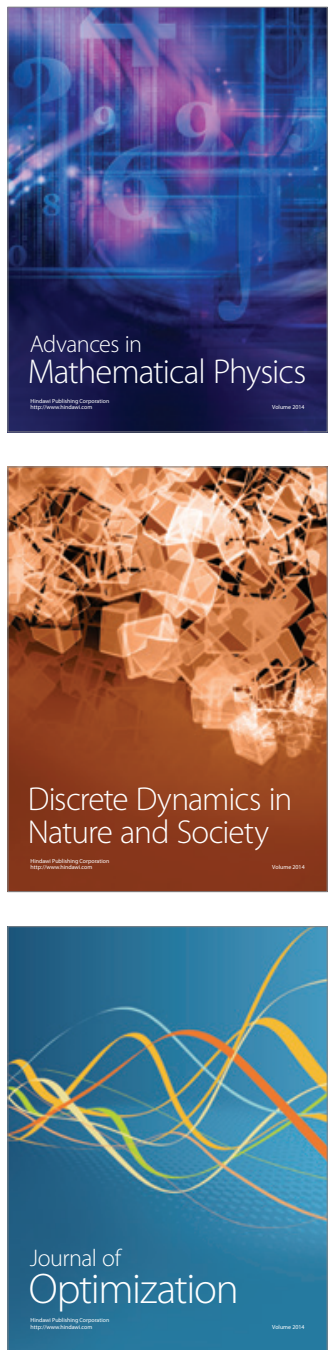